\title{
Male Breast Cancer: A Single-Center Experience
}

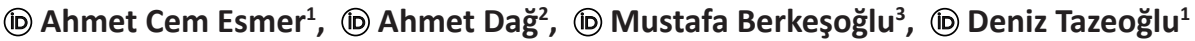 \\ ${ }^{1}$ M.D Spec., Mersin University, Faculty of Medicine, Clinic of Surgical Oncology, Mersin, Turkey. \\ ${ }^{2}$ Prof., Mersin University, Faculty of Medicine, Clinic of General Surgery, Mersin, Turkey. \\ ${ }^{3}$ Asst. Prof., Mersin University, Faculty of Medicine, Clinic of General Surgery, Mersin, Turkey. \\ Öz
}

Erkek Meme Kanseri: Tek Merkez Deneyimi

Amaç: Erkek meme kanseri (MBC), meme ve erkek kanserlerinin \%1’inden azını olușturan nadir bir hastalıktır. Bu yüzden MBC tedavi protokollerin çoğu kadınlar için meme kanseri tedavisi deneyiminden türetilmiștir. MBC, kadınlarda meme kanserinde olduğu gibi toplumsal farkındalık eksikliği nedeniyle genellikle ileri evrelerde saptanır. Bu çalışmada MBC ile ilgili klinik deneyimimizi güncel literatürle karșılaștırmayı amaçlanmıștır.

Gereç ve Yöntem: Mersin Üniversitesi Tıp Fakültesi Hastanesinde Ocak 2008-Ocak 2018 tarihleri arasında meme kanseri tanısı alan 21 erkek hastanın dosyalarını retrospektif olarak incelenmiștir.

Bulgular: Memede kitle nedeniyle kliniğimize 21 hasta bașvurmuștur. Bu hastaların 17'sinde primer MBC ve 4'ün de ise metastatik meme kitlesi tespit edilmiștir. Primer MBC hastalarının 15’ine cerrahi tedavi uygulanırken ve 2 hasta neoadjuvan tedaviye yönlendirilmiștir. Çoğu cerrahi vakada basit mastektomi uygulanmıştır. 7 hasta direkt olarak aksiller lenf nodu diseksiyonu (ALND) uygulanırken ve 8 hastaya sentinel lenf nodu biyopsisi (SLNB) uygulanmıștır. 4 hastada SLNB pozitif gelmesi üzerine ALND uygulanmıștır. 24 aylık (6-96 ay arası) takipte hiçbir hastada lokal nüks gelișmediği gözlenmiștir.

Sonuç: MBC'nin nadir olması, randomize klinik çalışmaları engellemektedir. MBC için klinik kararların çoğu, kadınlarda meme kanseri tedavisi deneyiminden türetilmiştir. MBC'yi daha iyi anlamak için daha fazla çalışmaya ihtiyaç vardır.

Anahtar Kelimeler: Aksiller Lenf Nodu Diseksiyonu, Erkek Meme Kanseri, Segmental Mastektomi, Sentinel Lenf Nodu Biyopsisi

\section{Abstract}

\section{Male Breast Cancer: A Single-Center Experience}

Objective: Male breast cancer (MBC) is a rare disease, accounting for less than $1 \%$ of breast and male cancers. Because of the low incidence, most of the clinical decisions for MBC have been derived from the experience of treatment of breast cancer in females. MBC is generally detected in advanced stages due to a lack of social awareness as it occurs in breast cancer in females. In this study, it was aimed to compare our clinical experience with $\mathrm{MBC}$ with current literature.

Methods: This study retrospectively reviewed 21 men who were diagnosed with MBC between January 2008 and January 2018 at the Department of General Surgery of Mersin University School of Medicine, Mersin, Turkey.

Results: Unilateral malign breast lesions were identified in 21 male patients that 17 are primary MBC and 4 metastatic breast lesions. 15 primary MBC patients underwent primary surgical treatment, and 2 patients were directed to neoadjuvant treatment. Simple mastectomies were performed in most surgical cases. 7 patients were directly addressed to axillary lymph node dissection (ALND), and sentinel lymph node biopsy (SLNB) was performed in 8 patients. 4 patients had tumor positivity in the settings of SLNB, and further ALND was performed subsequently in these cases. None of the patients developed local recurrence in the 24-month follow-up (range 6-96 months).

Conclusion: The rarity of $\mathrm{MBC}$ precludes randomized clinical trials. Most of the clinical decisions for MBC have been derived from the experience of treatment of breast cancer in females. Further studies are needed to understand better MBC.

Keywords: Axillary Lymph Node Dissection, Male Breast Cancer, Segmental Mastectomy, Sentinel Lymph Node Biopsy

Nasıl Atıf Yapmalı: Esmer AC, Dağ A, Berkeșoğlu M, Tazeoğlu D. Male Breast Cancer: A Single-Center Experience. MkÜ Tıp Dergisi. 2021;12(44):172-176. https://doi. org/10.17944/mkutfd.927704 


\section{INTRODUCTION}

Male breast cancer (MBC) is a rare disease, accounting for less than $1 \%$ of breast cancers $(1,2)$. Due to the low incidence of $\mathrm{MBC}$, treatment protocols derived from female breast cancer protocols. MBC is generally detected in advanced stages because there is insufficient social awareness about MBC and males are naturally out of screening programs. Muscle tissue involvement is more common in males due to less breast tissue. Therefore, patients with MBC are often candidates for mastectomy and lymph node dissection. Clinicopathologic features of tumors and lymph node status are the most important prognostic factors in breast cancer (3). Options for detecting lymph node status are sentinel lymph node biopsy (SLNB) or axillary lymph node dissection (ALND). Although SLNB is an effective procedure for lymph node staging in early breast cancer, ALND is usually performed because MBC patients present at an advanced stage. Unfortunately, ALND has well-known risks such as neurovascular injury, seroma formation, reduced mobility of the operated arm, and lymphedema. Raising awareness about MBC and performing less morbid procedures are valuable for the effective treatment of $\mathrm{MBC}$.

In this study, it was aimed to compare our clinical experience with MBC with current literature.

\section{MATERIALS AND METHODS}

This study retrospectively reviewed 21 men who diagnosed malignant tumors in the breast between January 2008 and January 2018 at the Department of General Surgery of Mersin University School of Medicine, Mersin, Turkey. Patients attended clinic with painless breast mass with or without nipple retraction. All patients were evaluated with the physical examination. Ultrasonography, mammography, and core needle biopsy were used in all patients. Computerized tomography (CT) or positron emission tomography - computerized tomography (PET-CT) was used for the assessment of disease progression in patients with suspected metastatic disease. Metastatic breast lesions originated from the other primary organ site were excluded from the study. Primary $M B C$ cases were evaluated in detail. While metastatic MBC cases were directed to primary chemotherapy, surgery was primarily performed for MBC patients without metastasis (surgical cases). Early breast cancer was defined as tumor size was smaller than $5 \mathrm{~cm}$ without fixed or conglomerated axillary nodes, or ipsilateral internal mammary, or infra/supraclavicular lymph nodes involvement. Type of surgery, such as segmental mastectomy or mastectomy, was decided based on patient preference, tumor size, location, and muscle involvement of the tumor. Simple mastectomy or segmental mastectomy was performed after detection of the sentinel lymph node (SLN). SLNB was performed in patients with clinically negative axillary lymph nodes, and ALND was performed in cases with clinically positive axillary lymph nodes. Both techniques of lymphoscintigraphy and patent blue painting were used together in all patients since the combination improves the intraoperative identification rate $\% 96.6-100 \%(4,5)$. SLNs were identified by either blued nodes and/or radioactive lymph nodes with an activity at least 10 times that of the background with a handheld gamma counter. Harvested SLNs were evaluated with immediate frozen section and embedded in paraffin for definitive diagnosis. When SLNs had any tumor involvement, it was considered positive. If the patients had positive SLNs based on the frozen section diagnosis, further ALND was performed at the same session. The results of frozen section of SLNs and the definitive section of SLNs were evaluated. SLNB negative and SLNB positive patients were evaluated in different groups. Classical immunohistochemistry (IHC) markers such as estrogen receptor (ER), progesterone receptor (PR), and human epidermal growth factor receptor 2 (HER2) were used for the determination of tumor subtype. Tumors were classified into four IHC-defined subtypes: HR+/ HER2-, HR+/HER2+, HR-/HER2+, and triple-negative (HR-/ HER2-) (6). MBC patients were staged according to the valid Tumor Node Metastasis system ( $7^{\text {th }}$ or $8^{\text {th }}$ TNM) at the time of diagnosis. Clinicopathologic data, including patient age, tumor size, tumor location, histological type of tumor, receptor status of the tumor, grade of tumor, stages, type of surgery, number of harvested SLNs, and follow-up period, were evaluated in detail.

\section{RESULTS}

Unilateral malign breast lesions were identified in 21 male patients. According to the final pathology report, 4 patients had breast lesions (metastatic) that originated from diverse primary sites other than MBC. Primary tumor origins of these patients were neuroendocrine tumors of lung $(n=2)$, hepatocellular carcinoma $(n=1)$, and prostate cancer $(n=1)$.

In this study, 17 primary MBC patients were evaluated in detail. The mean age of $\mathrm{MBC}$ is $64.8 \pm 12.87$ years. The mean tumor size was $25.3 \pm 14.42 \mathrm{~mm}$. The tumor was mostly left-sided (64.7\%), and lesions were mostly located in the retroareolar region (52.9\%).

The histological type of the MBC tumors was invasive ductal carcinoma $(n=8)$, invasive carcinoma of no special type (NST) $(n=4)$, papillary carcinoma $(n=3)$, apocrine carcinoma $(n=1)$, and mixed invasive micropapillary carcinoma $(n=1)$. While 13 patients had HR+/HER2- subtypes, four patients had $\mathrm{HR}+/$ HER2+. Pathological stages were IA $(n=3)$, IIA $(n=6)$, IIB $(n=2)$, IIIA $(n=2)$, IIIB $(n=1)$, IIIC $(n=1)$ and IV $(n=2)$ in MBC patients.

Most of the patients (88.2\%) underwent primary surgical treatment, and 2 patients were directed to neoadjuvant treatment (NAC) due to the advanced stage of their tumors. Simple 
mastectomies were performed in most surgical cases (93.3\%). 7 patients (\%41.2) were directly addressed to ALND, and SLNB was performed in 8 patients (\%47) (Table 1). 4 patients had tumor positivity in the settings of SLNB, and further ALND was performed subsequently in these cases. The results of frozen section were concordant with definitive pathologic results in all cases.

The mean age of the SLNB negative patients $(n=4)$ was $66.3 \pm 5.25$ years. The mean tumor size was $15.3 \pm 6.24 \mathrm{~mm}$. Two SLNs were harvested in two patients, and three SLNs were harvested in the other two patients (Table 1). Stages of the patients were IIA $(n=2), I A(n=1)$, and IIIA $(n=1)$. All patients had HR+/HER2- subtype in SLNB negative patients.

The mean age of the SLNB positive patients $(n=4)$ was 62.5 \pm 12.90 years. The mean tumor size was $27.8 \pm 14.36 \mathrm{~mm}$. Total harvested SLN numbers were 8, and metastasis was detected in 6 of these nodes. No additional metastatic nodes were detected in 2 patients (Table 1). Stages of the patients were IIA $(n=1)$, IIB $(n=1)$, IIIB $(n=1)$ and IIIC $(n=1) .2$ patients had HR+/HER2-, and 2 patients had HR+/HER2+ subtypes in SLNB positive patients.

The median follow-up was 24 months (range 6-96 months). Postoperative follow-up was uneventful in 13 surgical cases. However, one of the surgical cases and 2 NAC patients had disease progression. 2 surgical cases and two NAC patients died in the follow-up period. Two NAC patients progressed despite medical therapy and died without surgery at 6 and 11 months of diagnosis. The disease-recurrent surgical case had simple mastectomy with completion ALND infiltrating ductal carcinoma (stage IIIC and HR+/HER2+ subtype) previously. He had multiple distant metastases 46 months after the surgery and died at the 57 months of the surgery. Another disease-free patient who underwent mastectomy and ALND had no disease progression or metastasis and died due to heart failure at the 10th month after surgery.

\section{DISCUSSION}

MBC is rare and accounting less than 1\% of men's cancers (7). Risk factors are increasing age, radiation exposure, and factors related to abnormalities in estrogen and androgen balance such as testicular disease, infertility, obesity, and cirrhosis. Risk factors related to a genetic predisposition are Klinefelter syndrome, family history, and BRCA2 gene mutations. Although some risk factors are common in both gynecomastia and breast cancers, gynecomastia is not among the risk factors of $\mathrm{MBC}(8)$. In many ways, $\mathrm{MBC}$ resembles female breast cancer, but there are some differences. MBCs are seen slightly in older age with more frequent lymph node metastases, are a likely higher percentage of estrogen receptor-positive tumors and have a higher tumor stage at presentation compared to female breast cancer (9-11). In this study mean age of the patients are $64.8 \pm 12.87$ years old. Anderson et al. found estrogen receptor positivity rate \%92 among 5494

\section{Table 1. Characteristics of SLNB Patients}

\begin{tabular}{|c|c|c|c|c|c|c|c|c|c|}
\hline \multicolumn{2}{|l|}{ Age } & 71 & 57 & 75 & 47 & 63 & 63 & 74 & 65 \\
\hline \multicolumn{2}{|l|}{ Type } & NST & IDC & IDC & IDC & Papillary & NST & IDC & Micropapillary \\
\hline \multicolumn{2}{|l|}{ Location } & RA & U0Q & U0Q & RA & RA & U0Q & RA & LOQ \\
\hline \multicolumn{2}{|l|}{ Size(mm) } & 11 & 45 & 23 & 32 & 7 & 20 & 15 & 22 \\
\hline \multicolumn{2}{|l|}{ Stage } & $2 A$ & $2 \mathrm{~B}$ & $2 B$ & $3 C$ & $1 \mathrm{~A}$ & $1 \mathrm{~A}$ & $1 \mathrm{~A}$ & $2 \mathrm{~A}$ \\
\hline \multirow{2}{*}{ SLNB Lymph Nodes } & Positive & 1 & 1 & 1 & 3 & 0 & 0 & 0 & 0 \\
\hline & Total & 1 & 2 & 2 & 3 & 3 & 2 & 3 & 2 \\
\hline \multirow{2}{*}{ AL Lymph Nodes } & Positive & 1 & 0 & 0 & 5 & - & - & - & - \\
\hline & Total & 14 & 10 & 14 & 20 & - & - & - & - \\
\hline \multicolumn{2}{|l|}{ 0peration } & Simple M. & Simple M. & Simple M. & Simple M. & Simple M. & $\begin{array}{c}\text { Segmental } \\
\text { M.. }\end{array}$ & Simple M. & Simple M. \\
\hline \multicolumn{2}{|l|}{ ER (\%) } & 90 & 90 & 100 & 70 & 90 & 70 & 50 & 60 \\
\hline \multicolumn{2}{|l|}{ PR (\%) } & 40 & 75 & 80 & 60 & 70 & 50 & 2 & 40 \\
\hline \multicolumn{2}{|l|}{ Ki67(\%) } & 40 & $15-20$ & 10 & $50-60$ & 15 & 20 & 10 & 15 \\
\hline \multicolumn{2}{|l|}{ Her2/Neu } & 2 & N & N & 2 & N & N & N & 1 \\
\hline \multicolumn{2}{|l|}{ Grade } & $3(2+3+3)$ & $3(3+3+3)$ & $2(3+2+2)$ & $2(2+2+2)$ & $2(3+2+2)$ & $2(2+2+2)$ & $2(2+2+2)$ & $2(3+3+1)$ \\
\hline
\end{tabular}

ER: estrogen receptors; IDC: infiltrating ductal carcinoma; NST: invasive carcinoma of no special type; PR: progesterone receptors; RA: retroareolar region; U0Q: upper outer quadrant; L0Q: Iower outer lower quadrants; M: Mastectom 
MBC patients (12). In this study estrogen receptor positivity rate is \%95.8 that is compatible with the current literature. No patients had triple-negative subtypes.

MBC mostly presents with a painless subareolar palpable mass in the advanced stage (7-8). Patients in this study had mostly palpable breast mass, and $52.9 \%$ of the patients had tumor in the retroareolar region. Because of the low incidence, most of the clinical decisions for MBC have been derived from the experience of treatment of breast cancer in females. Thus, MBC shares many resembling characteristics with female breast cancers, such as sharing identical staging system, having analogous prognostic factors such as tumor size and lymph node status, affording similar surgical and adjuvant treatment options, and possessing comparable overall survival stage per stage of disease. 2 patients had metastasis at diagnosis and were directed to neoadjuvant treatment. Mastectomy is performed for most MBC patients in consequence of small breast tissue and retroareolar location of the tumor (13). Most patients (93.3\%) who underwent surgery had mastectomy in this study. MBCs are usually diagnosed in advanced stages, and patients are also candidates for ALND. However, some studies declared that SNLB is a useful technique in MBC (14-16). Several studies suggest SLNB in MBC with clinically negative axillary nodes. Sentinel node detection rate is between 96 and 100\% $(14,17,19)$. SLNB was performed for more than half of the patients (53.3\%), and SLNs were found in all these cases. Thus, some of these patients (26.7\%) were spared from ALND and subsequent complications in this study.

Post-operative complications like lymphedema, axillary neurovascular lesions, local healing problems, and decreased motion of the operated sidearm are seen in SLNB less than $\operatorname{ALND}(2,5)$. Another problem in SLNB is false positivity in frozen section, leads further surgical procedure for the patient, but numbers of the false results decrease with developing immunohistochemistry and molecular techniques (20).

The prognosis of $\mathrm{MBC}$ is related to the stage of the disease. Five-year survival in MBC is similar to survival in female breast cancer at the same stages (12). Female breast cancer five-year survival rate among the stages are $\% 100$ for Stage 0 and 1, \%93 for Stage 2, \%72 for Stage 3 and \%22 for Stage 4, while MBC five-year survival rates are \%100 for Stage 0 and 1, $\% 91$ for Stage 2, \%71 for Stage 3 and \%20 for Stage 4. In this study one surgical case (6.7\%) had distant metastasis and disease-related death in the follow-up period. That patient also had advanced stage (3C) tumor at the diagnosis.

\section{CONCLUSION}

$M B C$ is a rare entity and is often diagnosed in an advanced stage that prevents SNLB. SLNB is feasible, useful, safe, and reliable technique for MBC. SLNB may be performed in both early MBC, and eligible advance staged patients to avoid unnecessary ALND and subsequent morbidities. The rarity of MBC precludes randomized clinical trials. Thus diagnosis, staging, management, and prognosis of MBCs are derived from studies that are not performed on men. Further studies are needed to understand MBC.

\section{ACKNOWLEDGEMENT}

Peer-Review

Externally/Internally Peer Reviewed

Conflict of Interest

The authors declare that they have no conflict of interests regarding content of this article..

Financial Support

The Authors report no financial support regarding content of this article.

Ethical Declaration

Ethical approval was obtained from the Mersin University, Clinical Research Ethics Committee for this study with date 05/02/2020 and number 2020/85, and Helsinki Declaration rules were followed to conduct this study.

Support Resources

No financial support was used by authors during this study.

\section{REFERENCES}

1. Donegan WL, Redlich PN. Breast cancer in men. Surg Clin North Am. 1996 Apr;76(2):343-63. https://doi.org/10.1016/ s0039-6109(05)70443-6

2. Fentiman IS, Fourquet A, Hortobagyi GN. Male breast cancer. Lancet. 2006 Feb 18;367(9510):595-604. https://doi. org/10.1016/S0140-6736(06)68226-3

3. Fisher B, Bauer M, Wickerham DL, Redmond CK, Fisher ER, Cruz AB, Foster R, et al. Relation of number of positive axillary nodes to the prognosis of patients with primary breast cancer An NSABP update. Cancer. 1983 Nov 1;52(9):1551-7. https:// doi.org/10.1002/1097-0142(19831101)52:9<1551::aidcncr2820520902>3.0.c0;2-3

4. D'Eredita G, Giardina C, Guerrieri AM, Berardi T. A further validation of subareolar injection technique for breast sentinel lymph node biopsy. Ann Surg Oncol. 2006 May;13(5):701-7. https://doi.org/10.1245/ASO.2006.04.027

5. Díaz Brito JA, Navarrete SV, Muñoz JA, Guardiola YS, Sánchez JG Ruiz VV, et al. Sentinel node biopsy in early breast cancer at the Hospital Comarcal La Linea (Spain). Ecancermedicalscience. 2013 Sep 23;7:353. https://doi.org/10.3332/ecancer.2013.353

6. Cejalvo JM, Pascual T, Fernández-Martínez A, Brasó-Maristany F, Gomis RR, Perou CM, Muñoz M, Prat A. Clinical implications of the non-luminal intrinsic subtypes in hormone receptorpositive breast cancer. Cancer Treat Rev. 2018 Jun;67:63-70. https://doi.org/10.1016/j.ctrv.2018.04.015 
7. Speirs V, Shaaban AM. The rising incidence of male breast cancer. Breast Cancer Res Treat. 2009 May;115(2):429-30. https://doi.org/10.1007/s10549-008-0053-y

8. Zygogianni AG, Kyrgias G, Gennatas C, Ilknur A, Armonis V, Tolia $\mathrm{M}$, et al. Male breast carcinoma: epidemiology, risk factors and current therapeutic approaches. Asian Pac J Cancer Prev. 2012;13(1):15-9. https://doi.org/10.7314/арjср.2012.13.1.015

9. Leone, J.P., Leone, J., Zwenger, A.O., Iturbe, J., Vallejo, C.T. and Leone, B.A. Prognostic significance of tumor subtypes in male breast cancer: a population-based study. Breast Cancer Res Treat. 2015;152:601-609 https://doi.org/10.1007/s10549-0153488-y

10. Anderson WF, Althuis MD, Brinton LA, Devesa SS. Is male breast cancer similar or different than female breast cancer? Breast Cancer Res Treat. 2004 Jan;83(1):77-86. https://doi. org/10.1023/B:BREA.0000010701.08825.2d

11. Cardoso F, Bartlett JMS, Slaets L, van Deurzen CHM, van Leeuwen-Stok E, Porter $P$, et al. Characterization of male breast cancer: results of the EORTC 10085/TBCRC/BIG/NABCG International Male Breast Cancer Program. Ann Oncol. 2018 Feb 1;29(2):405-417. https://doi.org/10.1093/annonc/mdx651

12. Anderson WF, Jatoi I, Tse J, Rosenberg PS. Male breast cancer: a population-based comparison with female breast cancer. J Clin Oncol. 2010;28(2):232-239. https://doi.org/10.1200/ JCO.2009.23.8162

13. Kiluk JV, Lee MC, Park CK, Meade T, Minton S, Harris E, Kim J, Laronga C. Male breast cancer: management and follow-up recommendations. Breast J. 2011 Sep-Oct;17(5):503-9. https:// doi.org/10.1111/j.1524-4741.2011.01148.x
14. Gentilini O, Chagas E, Zurrida S, Intra M, De Cicco C, Gatti G, et al. Sentinel lymph node biopsy in male patients with early breast cancer. Oncologist. 2007 May;12(5):512-5. https://doi. org/10.1634/theoncologist.12-5-512

15. Flynn LW, Park J, Patil SM, Cody HS 3rd, Port ER. Sentinel lymph node biopsy is successful and accurate in male breast carcinoma. J Am Coll Surg. 2008 Apr;206(4):616-21. https:// doi.org/10.1016/j.jamcollsurg.2007.11.005

16. Hill AD, Borgen PI, Cody HS 3rd. Sentinel node biopsy in male breast cancer. Eur J Surg Oncol. 1999 Aug;25(4):442-3. https:// doi.org 10.1053/ejso.1999.0674

17. Cimmino VM, Degnim AC, Sabel MS, Diehl KM, Newman LA, Chang AE. Efficacy of sentinel lymph node biopsy in male breast cancer. J Surg Oncol. 2004 May 1;86(2):74-7. https://doi. org/10.1002/jso.20045

18. Albo D, Ames FC, Hunt KK, Ross MI, Singletary SE, Kuerer HM. Evaluation of lymph node status in male breast cancer patients: a role for sentinel lymph node biopsy. Breast Cancer Res Treat. 2003 Jan;77(1):9-14. https://doi. org/10.1023/a:1021173902253

19. Boughey JC, Bedrosian I, Meric-Bernstam F, Ross MI, Kuerer HM, Akins JS, et al. Comparative analysis of sentinel lymph node operation in male and female breast cancer patients. J Am Coll Surg. 2006 Oct;203(4):475-80. https://doi. org/10.1016/j.jamcollsurg.2006.06.014

20. Martin-Marcuartu JJ, Alvarez-Perez RM, Sousa Vaquero JM, Jimenez-Hoyuela García JM. Selective sentinel lymph node biopsy in male breast cancer. Rev Esp Med Nucl Imagen Mol (Engl Ed). 2018 May-Jun;37(3):146-150. English, Spanish. https://doi.org/10.1016/j.remn.2017.09.004 